Vol. 10, Issue 10, October 2021

DOI: $10.17148 /$ IJARCCE.2021.101003

\title{
INNOVATION IN E-BUSINESS
}

\author{
Priyanka Shiyal ${ }^{1}$, Danella Patnaik ${ }^{2}$, Roshni Yadav \\ ${ }^{1,2,3} \mathrm{NSM}$ degree college students of SYBMS, Mumbai
}

\begin{abstract}
In simple words, innovation is an organisations process for introducing new ideas, methods, services, products etc. Business innovation should extend new customs. In the sphere of business, there are numerous innovations that an enterprise pursues. The best phrase we catch is "ADAPT OR DIE" to attain success in today's modernism. Sample of innovations in E-business is Blockchain, Single click check-out, Digital storefronts and the rest
\end{abstract}

keywords: Innovations, new customs, the sphere of business, enterprise, adapt or die, modernism

\section{INTRODUCTION:-}

\section{"EVERY SECOND YOU SPEND THINKING ABOUT WHAT SOMEBODY ELSE HAS IS TAKING AWAY FROM TIME THAT YOU COULD CREATE SOMETHING FOR YOURSELF "}

Great e-commerce branding is all about creation, ideas \& relationships. Focus on bringing positive energy into the world \& make your brand one that people remember for the right reasons. Be authentic.

Business is the activity of making one's living or making hard cash by manufacturing or buying and selling products such as:-

1)Goods and services

2)Need references to verify

Simply, it is "any activity or venture entered into for profit".

The term E-Business was originated by IBM'S marketing \& web term in 1996. Doing business with the help of an internet network can be termed as E-Business. It is a type of business or mercantile of products and services between businesses, groups and solo and can be visible as one of the necessary activities of any business. It concentrates on the use of ICT (Information Communication Technology) to empower the outer activities \& connections of the business with singular, groups \& other businesses.

\section{AIMS AND OBJECTIVES:}

E-business is known and used everywhere and helped many people in buying and selling

Our aim of taking this topic as research are as follows

1)To know the advantage and disadvantages of E-Business

2) To gain more knowledge in E-business

3) To make people aware of innovation that has been taken in E-business

4)To understand to what extent innovation has helped E-Business in growing

5) What more innovation can be done in E-Business

\section{METHODOLOGY :}

- In thi s research paper, to study innovation in E-Business we used secondary data, in that we used the published source methods.

- $\quad$ websites and article sources :

eCommerce tips, shaala, WordPress,

- Due to these websites and articles, we found detailed information about our topic that helped us in our research paper.

\section{ADVANTAGES, DISADVANTAGES \& INNOVATIONS USED IN E-BUSINESS:-}

\subsection{ADVANTAGES:-}

1)E-Business Saves Money:-

Forgoing the traditional model of a brick-and-mortar location means small-business owners save a tremendous amount of money at startup. If you sell products, they no longer have to go from manufacturer to warehouse to store to the 
customer's cart, they can go from the manufacturer to the customer's virtual cart, which saves on shipping costs and makes products cheaper overall.

\title{
2)Better Communication and Faster Decision-Making:-
}

E-business allows for conversations to for the most part happen quickly. Faster decision-making saves time, and time is money in business, which is quite significant. E-business allows people to communicate in several ways that essentially facilitate understanding. If someone is not comfortable on the phone or through a video chat, there generally is always messaging and emailing, which is quite significant. People who don't speak the same language can mostly subtly communicate through translation software programs.

\section{3)Cheaper Marketing, More Control:-}

Traditionally, companies had to rely on advertising agencies to promote their brand and educate people about it. Now there are lots of ways to mostly pour money back into for all intents and purposes your business, which for the most part is quite significant. When you control how your product is represented, you control your company. E-business allows owners to kind of embrace their power in ways they haven't been able to before.

\section{4)More Avenues for Making Money:-}

Most products and services that were traditionally available can be managed and sold on the internet. Selling goods or services, virtual retail stores, education, legal services, medical services - there is no end to businesses that can flourish in the modern e-commerce market. Existing businesses can expand into e-businesses, or entrepreneurs can start new ebusinesses quickly and less expensively than in the past.

\section{5)E-Business Means Freedom:-}

Many small businesses thrive due to the options technology has granted. Opening an e-business means freedom - freedom of location, freedom to dictate the hours you work, and the freedom to push your company where you want it to go in ways that best suit your lifestyle, goals and needs.

\subsection{DISADVANTAGES:-}

1)Quicker Market Share Loss Because of the Competition:-

With an e-business, there is the danger of corporate vulnerability as you stand to the risk of speedier market share loss because of competition from home and abroad. This is the only way to avoid a substantial loss to your business.

\section{2)High Startup Costs Especially with Marketing:-}

With an e-business, the merchant is competing against other merchants worldwide. This global competition increases your startup cost and your digital marketing cost for search engine optimization. Pay per click advertising is an effective way to ensure that you only pay for adverts viewed by actual humans.

\section{3)Handling Returns:-}

There is a limit to how you can describe a product on screen. You need to meditate on these things when adopting an ebusiness, especially if you will deal with physical products. The poor handling of returns and charges can have long-term legal and financial implications for your business.

\section{4)Innovation Pressure:-}

An e-business model exposes you to a global competitive field, and there is a tendency for your brand's voice to be drowned out in a sea of several thousand competitors. It would help if you also innovated your supply chain to meet your customers' expectations.

\section{5)Customers Can generally Remain Anonymous:-}

Depending on the e-commerce platform or CRM platform with the use of e-business, there is the tendency for your customers to generally stay anonymous since you are not relating to them face-to-face, and sometimes, their business interaction with you might be a one-off affair, or so they thought.

\subsection{DIFFERENT TYPES OF E-BUSINESS}

\author{
1)Business-to-Business (B2B) \\ 2)Business-to-Consumer (B2C) \\ 3)Consumer-to-Consumer (C2C) \\ 4)Consumer-to-Business (C2B) \\ 5)Business-to-Administration (B2A) \\ 6)Consumer-to-Administration (C2A)
}


1)Business-to-Business (B2B):-

A B2B model of business involves the conduct of trade between two or more businesses/companies. The channels of such trade generally include conventional wholesalers and producers who are dealing with retailers.

\section{2)Business-to-Consumer (B2C):-}

Business-to-Consumer model of business deals with the retail aspects of e-commerce, i.e. the sale of goods and services to the end consumer through digital means. The facility, which has taken the business world by storm, enables the consumer to have a detailed look at their proposed procurements before placing an order. After the placement of such orders, the company/agent receiving the order will then deliver the same to the consumer in a convenient period. Some of the businesses operating in this channel include well-known players like Amazon, Flipkart, etc. This mode of purchase has proved to be beneficial to the consumers when compared to the traditional method, as they are endowed with access to helpful content which may guide their purchases appropriately.

\section{3)Consumer-to-Consumer (C2C):-}

This business model is leveraged by a consumer for selling used goods or services to other consumers through the digital medium. The transactions here are pursued through a platform provided by a third party, the likes of which include OLX, Quickr, etc.

\section{4)Consumer-to-Business (C2B):-}

A C2B model is the exact reversal of a B2C model. While the latter is serviced to the consumer by a business, the C2B model provides the end consumers with an opportunity to sell their products/services to companies. The method is popular in crowdsourcing based projects, the nature of which typically includes logo designing, sale of royalty-free photographs/media/design elements, and so on.

\section{5)Business-to-Administration (B2A):-}

This model enables online dealings between companies and public administration, i.e. the Government by enabling the exchange of information through central websites. It provides businesses with a platform to bid on government opportunities such as auctions, tenders, application submission, etc. The scope of this model is now enhanced, thanks to the investments made towards e-government.

\section{6)Consumer-to-Administration (C2A):-}

The C2A platform is meant for consumers, who may use it for requesting information or posting feedbacks concerning public sectors directly to the government authorities/administration. Its areas of applicability include:

a) The dissemination of information.

b)Distance learning.

c) Remittance of statutory payments.

d) Filing of tax returns.

Seeking appointments, information about illnesses, payment of health services, etc.

\subsection{INNOVATION USED IN E-BUSINESS}

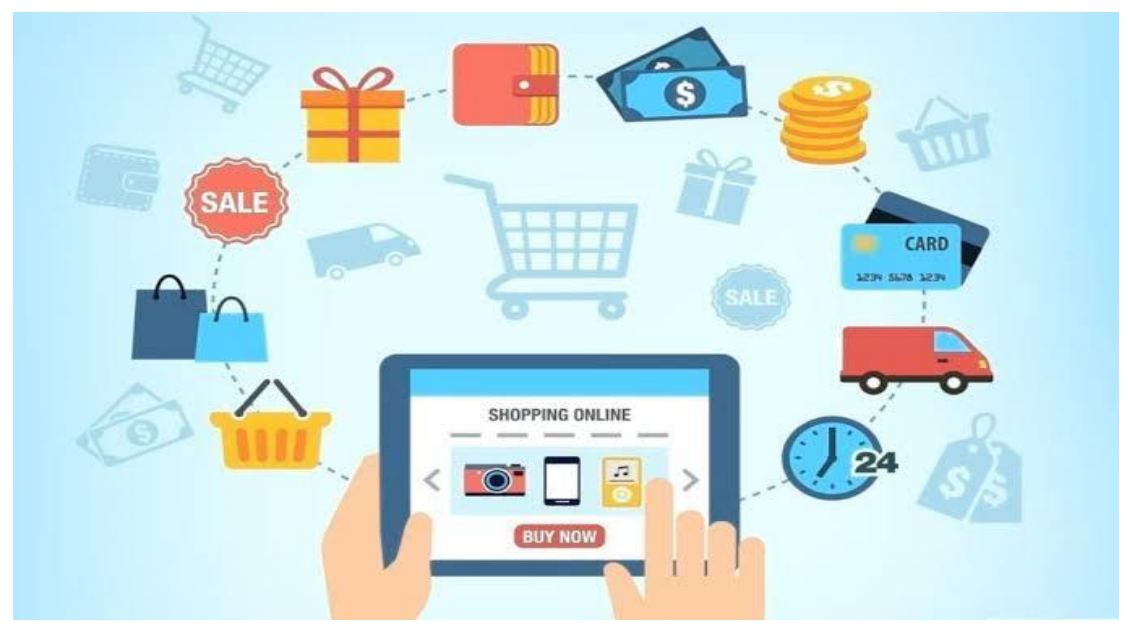


1)BLOCKCHAIN:- Blockchain the revolutionary technology that energizes cryptocurrencies can help add lucidity to supply chains, providing consumers with answers to their interrogation, adds more transparency to E-business

2) SINGLE-CLICK CHECKOUT:- It decreases shopping cart abandonment rater, which helps consumers, and improves all-inclusive sales for a speedy transaction

3)DIGITAL STOREFRONTS:- Digital storefronts is a website where we see the collection of products and related information about the product.

4)AUDIO SHOPPING:-Consumers can search for their product through voice.

5)VISUAL SEARCH:-You can search a specified or particular product due to visual search.

\section{SUGGESTIONS:-}

- Most of the reason why people find it risky to shop online is that trust issue .customer think they might get cheated in terms of quality or quantity of goods. so businessman by doing online E-Business needs to be loyal to its customers they need to provide the customers with the goods and services that are displayed In their website

- Sales and offers are the best tool to attract customers Sales like woman day special, Ganesh Chaturthi offers should keep ongoing

- The process of payment should be simple sometimes customers may prefer to purchase your product but due to the long and complicated process of payment, they might get frustrated and prefer not to purchase online.

For eg: Name, Address, phone number, credit card number

- There should be a Feedback or comment section where the customer can share their point of view or any queries they are facing and also all their queries and should be answered and solved quickly, by this the customer will feel that you are listing to them and they won't be disappointed.

\section{CONCLUSION:-}

E-Business known as E-Commerce has made an impact all over the world. The technology has been upgraded and many innovations have taken place in E-Business. For the "growth and survival" of E-Business Innovation should be carried out, Innovation such as blockchain, digital storefronts, single checks and much more innovation that entice the customers towards E-business and also such innovation helps in the expanding E-Business. A businessman should master themselves in excogitating ideas in E-Business. By sharing their work and ideas on social media many people can start their online businesses. E-business has brought negative and positive impact in society but as a customer and user, we must keep E-business stable and healthy. I would conclude by saying many innovations has been taken into consideration to solve customer queries, to make E-Business suitable for everyone, and also for E-Business to develop in many ways.

\section{REFERENCES:-}

1)https://ecommercetips.org

2)http://ijstem.com

3)https://www.icecubedigital.com

4)https://www.formpl.us.

5)https://www.shaala.com

6)https://www.google.com/amp/s/steph31719.wordpress.com/2009/11/17/conclusion-in-progress/amp/

7) https://www.indiafilings.com

8)https://en.m.wikipedia.org

9)https://mauconline.net

10) https://smallbusiness.chron.com

11)https://businesswalls.blogspot.com/2020/08/e-commerce-need-of-todays-business.html?m=1

12)https://www.europeanbusinessreview.com/innovation-trends-in-ecommerce-for-2020/

13)https://www.wordstream.com/blog/ws/2016/02/03/increase-sales-online 14)https://link.springer.com/chapter/10.1007/978-3-642-05197-5_1

15) https://youtu.be/dEx0Q4DWxMs 